\title{
INVESTIGATION OF FOUR PHASE INTERLEAVED BOOST CONVERTER UNDER OPEN LOOP AND CLOSED LOOP CONTROL SCHEMES FOR BATTERY CHARGING APPLICATIONS
}

\author{
Pridhivi Prasanth*, Dr. R. Seyezhai** \\ *Research Assistant, SSN College of Engineering, Chennai, India \\ **Associate Professor, SSN College of Engineering, Chennai, India
}

\begin{abstract}
One of the main requirements for battery charging applications is constant output voltage and fewer ripples in the output voltage. Boost converters are used in places where the magnitude of the supply voltage is low. But in conventional boost converters, the magnitude of ripple in both the input current and output voltage are high which is not desired. While the input current ripple is reduced in conventional boost converter, the size of the components used is large. In order to reduce the ripples along with reduction in the component size, interleaving concept used. This paper focusses on the operation of four phase interleaved boost converter both in open and closed loop schemes. In the closed loop operation, current control mode is employed because of its faster response to changes along with simpler compensation and high gain bandwidth compared to the voltage control mode. The simulation of the circuit is carried out in MATLAB/SIMULINK and the results are validated for both the schemes.
\end{abstract}

\section{Keywords:}

Interleaving, input current ripple, output voltage ripple, current control mode

\section{Introduction}

A boost converter is basically a step up converter with an output DC voltage greater than its input DC voltage. It consists of a semiconductor switch, a diode and an energy storage element. In order to reduce the output voltage ripple, filters in the form of capacitors are normally added at the output of the capacitor [1].

The basic operation of the boost converter is such that the input voltage in series with the inductor acts as a current source. During the turn on of the switch, the inductor stores energy and during turn off of the switch, the combined energy of the source and the discharging inductor is applied to the load, thus boosting the input voltage. The load consists of a resistor connected in parallel to a filter capacitor. The capacitor is large in order to maintain constant output voltage and also reduce the ripple in the output voltage [2].

In conventional boost converter, the magnitude of ripple in the output voltage is high which is not desirable for battery charging applications. By the concept of interleaving, the output voltage ripple along with input current ripple is reduced to a value depending upon the duty cycle of 
International Journal of Advances in Materials Science and Engineering (IJAMSE) Vol.5, No.1, January 2016 operation [3]. For example, in two phase operation of boost converter, minimum ripple is obtained at $50 \%$ duty cycle and in three phase operation at $33 \%$ and $66 \%$ [4].

In four phase boost converter, minimum ripple is obtained at duty cycles $25 \%, 50 \%$ and $75 \%$. If the conventional boost converter is operated at a particular duty cycle, the ripple value obtained for the same duty cycle operation in the four phase boost converter will be less compared to the ripple obtained in the conventional one. Another advantage of four phase operation is that an an time at least one of the converters is supplying the load in addition to the capacitor. Thus, the value of the output capacitor decreases [5].

Also interleaving reduces the size of the storage devices used compared to the conventional boost converter. This reduction can also be done with increasing the switching frequency, but it is not practicable always. Moreover, the input current ripple, output capacitor RMS current and the output voltage ripple vary with changes in the duty cycle. Hence, by appropriately selecting the duty cycle, the ripple can be minimised in both the input current and output voltage ripple [6]. The closed loop operation of the four phase boost converter is also investigated in this paper. Closed loop current control mode is applied to the four phase converter because of its advantages over voltage mode control [7]. The main advantage of operating in closed loop scheme is that the ripple values are furthermore reduced compared to open loop operation of the converter. Additionally, the closed loop ensures that constant output voltage is maintained even if there is any load variation or input voltage variation [8].

\section{Four phase boost converter operated in open loop scheme}

The circuit diagram for four phase interleaved boost converter is shown in figure 1. It is simply four boost converters connected in parallel with each phase operating $90^{\circ}$ out of phase. It consists of four inductors, switches and diodes operating in parallel. The load used here is a resistive load. At any time, at least one of the phases is supplying to the load in addition to the output capacitor.

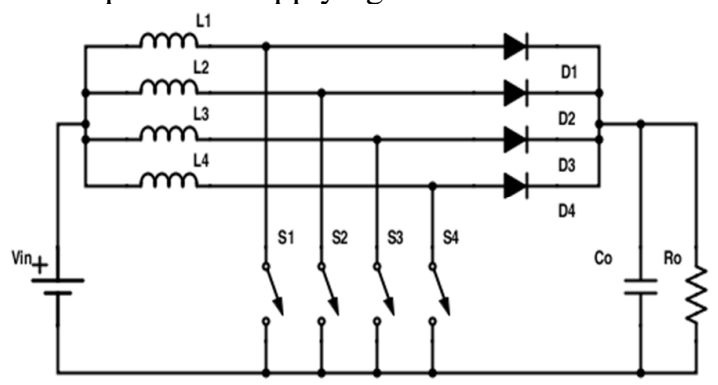

Figure 1 Four phase boost converter diagram

The input current is the sum of four inductor currents $\mathrm{I}_{\mathrm{L} 1}, \mathrm{I}_{\mathrm{L} 2}, \mathrm{I}_{\mathrm{L} 3}$ and $\mathrm{I}_{\mathrm{L} 4}$. Since the inductor ripple currents are out of phase, they tend to cancel and thus reduce the input ripple caused by the boost inductors. 


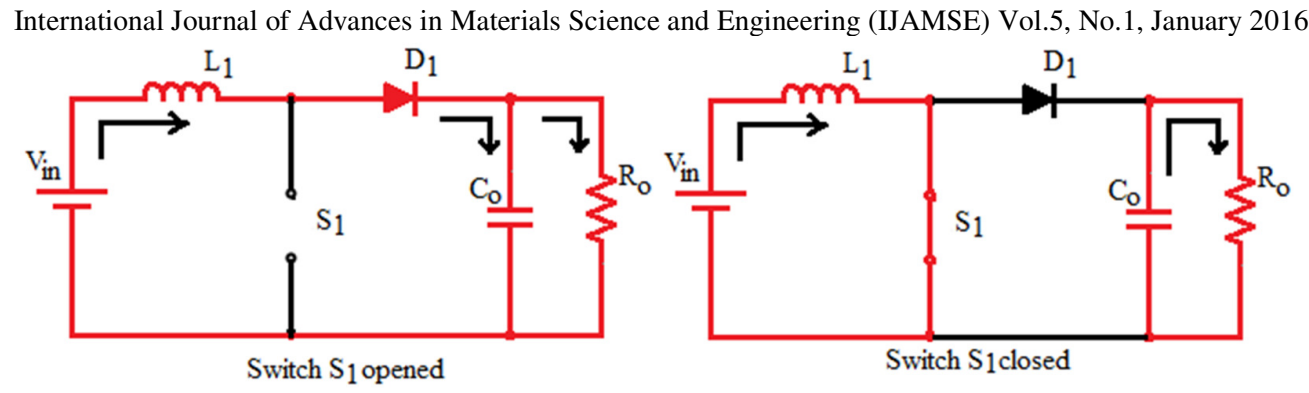

Figure 2 Operation of one phase of the converter

As shown in Figure 2, when the switch $S_{1}$ is closed, the inductor $L_{1}$ begins to charge from the source $V_{\text {in }}$. During this time, the load $R_{o}$ is supplied by the capacitor which was charged during the previous instant. When switch $S_{1}$ is opened, the load is supplied by both the charge from both the source $V_{i n}$ and the charge stored in the inductor $L_{1}$. Since, both $V_{i n}$ and $L_{1}$ are in series, it results in a higher voltage which charges the capacitor $C_{0}$ through the diode $D_{1}$. This similar operation continuous in the four phase boost converter [9].

\section{Design equation for four phase interleaved boost converter 3.1 Gate pulse:}

The gate pulses for the four phase interleaved boost converter are phase shifted according to the following formula

$$
\theta=\frac{360^{\circ}}{n}
$$

where $\mathrm{n}$ is the number of phases chosen for the boost converter.

\subsection{Output voltage:}

The relation between input and output voltage is as follows,

$$
V_{o}=\frac{V_{\text {in }}}{1-D}
$$

where $V_{\mathrm{o}}$ is the output voltage of the converter

$\mathrm{V}_{\text {in }}$ is the input voltage of the converter

$\mathrm{D}$ is the duty cycle of operation

\subsection{Boost inductor and output capacitor:}

The boost inductors $\mathrm{L}_{1}, \mathrm{~L}_{2}, \mathrm{~L}_{3}$ and $\mathrm{L}_{4}$ are calculated based on parameters such as switching frequency $\mathrm{f}_{\mathrm{s}}$, input and output voltages, $\mathrm{V}_{\mathrm{in}}$ and $\mathrm{V}_{\text {out }}$ and the inductor current ripple $\Delta \mathrm{I}_{\mathrm{L}}$ [10].

$$
L_{1}=L_{2}=L_{3}=L_{4}=\frac{V_{\text {in }} *\left(V_{o}-V_{i n}\right)}{\Delta I_{L} * f_{S} * V_{o}}
$$

The output capacitor is calculated using the below formula

$$
C_{o}=\frac{D * V_{o}}{f_{S} * R * \Delta V_{o}}
$$

where $\Delta \mathrm{V}_{\mathrm{o}}$ is the output voltage ripple. 
International Journal of Advances in Materials Science and Engineering (IJAMSE) Vol.5, No.1, January 2016

\section{Simulation parameters:}

Based on the equations (1), (2), (3) and (4), the parameters for simulation are shown in table 1.

\begin{tabular}{|c|c|}
\hline Parameter & Value \\
\hline Input voltage $\left(\mathrm{V}_{\text {in }}\right)$ & $26 \mathrm{~V}$ \\
\hline Duty cycle( $(\mathrm{D})$ & $46 \%$ \\
\hline Switching frequency $\left(\mathrm{f}_{\mathrm{s}}\right)$ & $100 \mathrm{kHz}$ \\
\hline Inductors $(\mathrm{L} 1$ and $\mathrm{L} 2)$ & $441.42 \mu \mathrm{H}$ \\
\hline Output capacitor $\left(\mathrm{C}_{\mathrm{o}}\right)$ & $12.5 \mu \mathrm{F}$ \\
\hline Output resistor $(\mathrm{R})$ & $65.82 \Omega$ \\
\hline
\end{tabular}

Table 1 Simulation parameters for four phase boost converter

The gating pattern for the four phase interleaved boost converter is shown in figure 3 ,

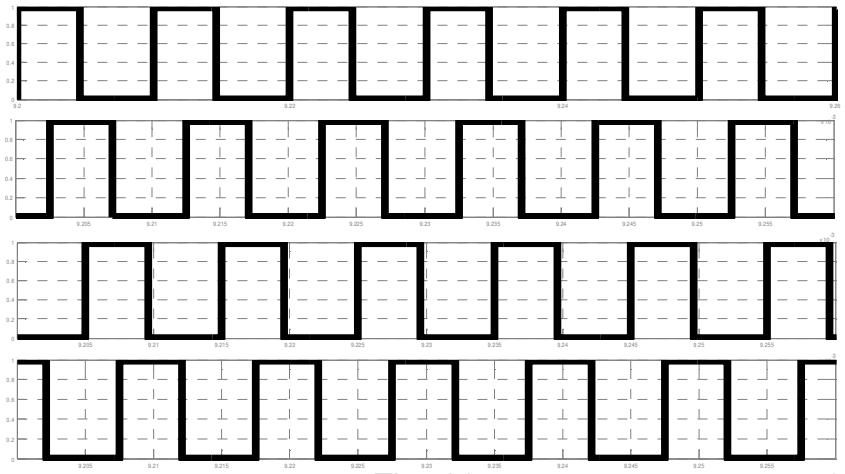

Figure 3 Gating pattern for four phase boost converter

Since the chosen number of phases for operation is four, the gate pulses for the switches are phase shifted by $90^{\circ}$.

\section{Open loop simulation results:}

The four phase interleaved boost converter was simulated in open loop mode. Figure 4 shows the output voltage waveform.

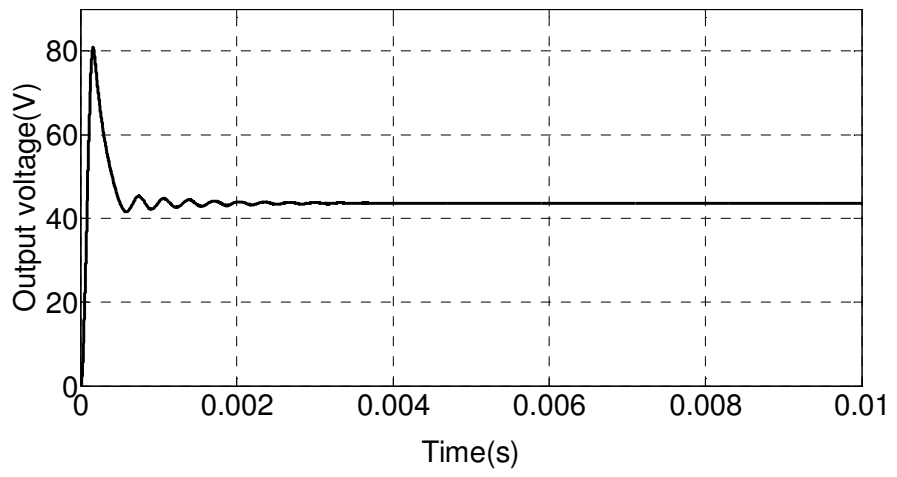

Figure 4 Output voltage waveform for open loop mode 
International Journal of Advances in Materials Science and Engineering (IJAMSE) Vol.5, No.1, January 2016

The variation of input current ripple with duty cycle is simulated and plotted as shown in figure 5 .

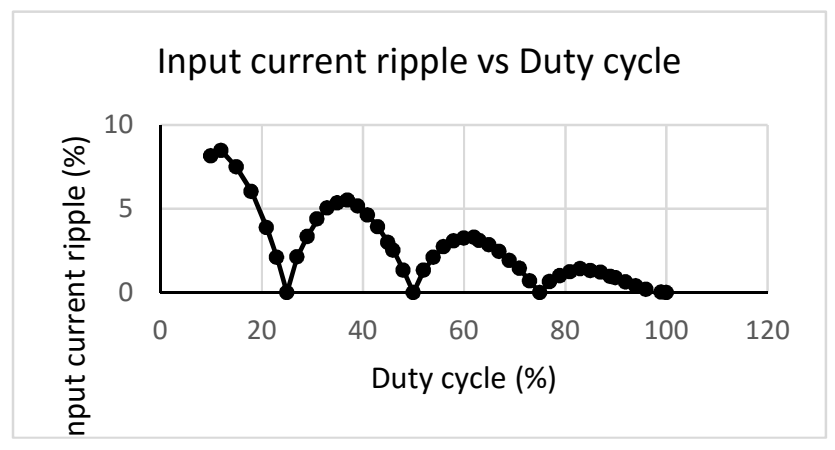

Figure 5 Input current ripple vs duty cycle

Similarly, the variation of output voltage ripple with duty cycle is shown in figure 6 .

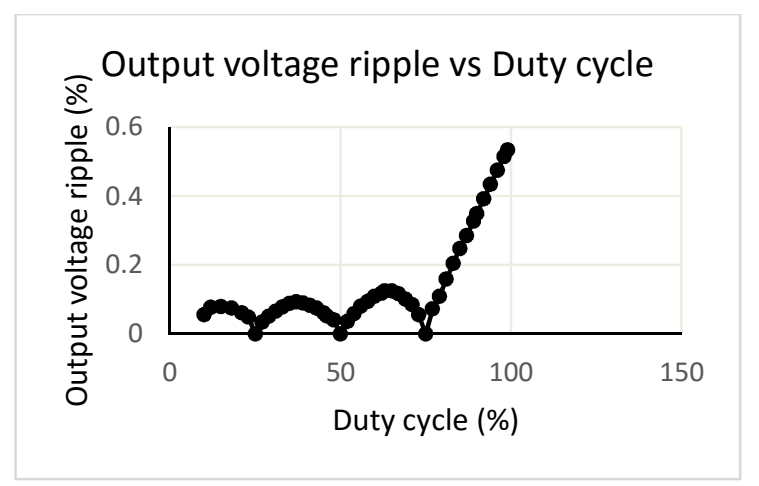

Figure 6 Output voltage ripple vs duty cycle

The capacitor Root Mean Square (RMS) current varies with the duty cycle according to the formula below,

$$
I_{R M S}=\left\{\begin{array}{c}
\frac{1}{4} \sqrt{(1-4 D)-(1-4 D)^{2}} \text { if } D \leq \frac{1}{4} \\
\frac{1}{4} \sqrt{(2-4 D)-(2-4 D)^{2}} \text { if } \frac{1}{4}<D<\frac{2}{4} \\
\frac{1}{4} \sqrt{(3-4 D)-(3-4 D)^{2}} \text { if } \frac{2}{4}<D<\frac{3}{4} \\
\frac{1}{4} \sqrt{(4-4 D)-(4-4 D)^{2}} \text { if } D \geq \frac{3}{4}
\end{array}\right.
$$

The capacitor RMS current for various values of duty cycles is simulated and the variation is shown in figure 7 . 


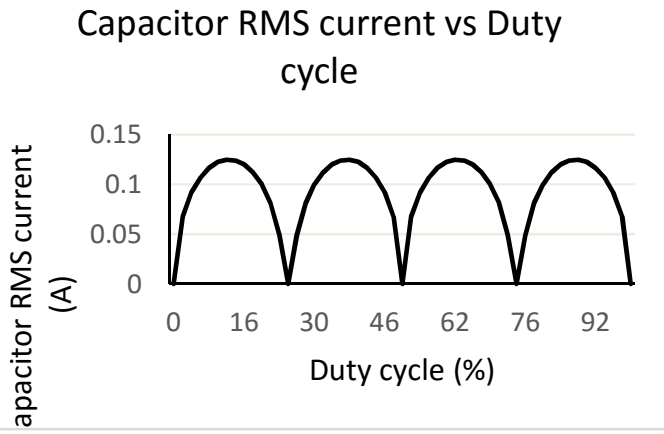

Figure 7 Capacitor RMS current vs duty cycle

The interleaving phenomenon thus can reduce the output capacitor RMS current. With addition of each individual phases, the RMS current continues to reduce. But, the amount of reduction decreases with each additional phase. In four phase interleaved boost converter, the output capacitor RMS current is reduced to $0.12 \mathrm{~A}$ compared to the conventional boost converter where the RMS current is 0.5A [11]. This reduction in RMS current will reduce the electrical stress in the output capacitor and improve the converter's reliability.

Also, depending on the design parameters, the interleaving phenomenon can reduce the size of the EMI filter. From graph 1, if the converter is operated at duty cycles $25 \%, 50 \%$ or $75 \%$, the inductor ripple currents cancel out [12]. Hence, the EMI filter would be drastically reduced by just interleaving.

The output voltage ripple, input current ripple and inductor current ripple are shown in figures 8 , 9 and 10.

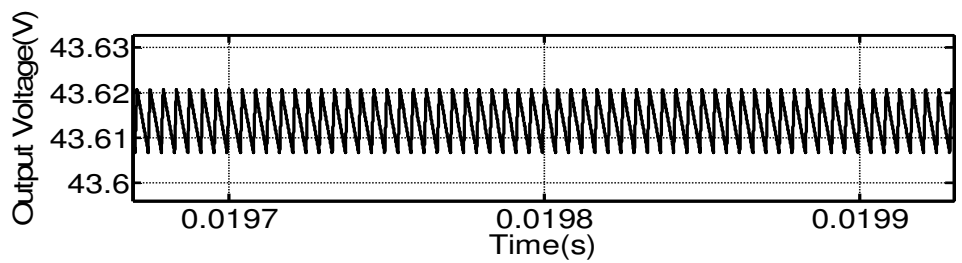

Figure 8 Output voltage ripple waveform

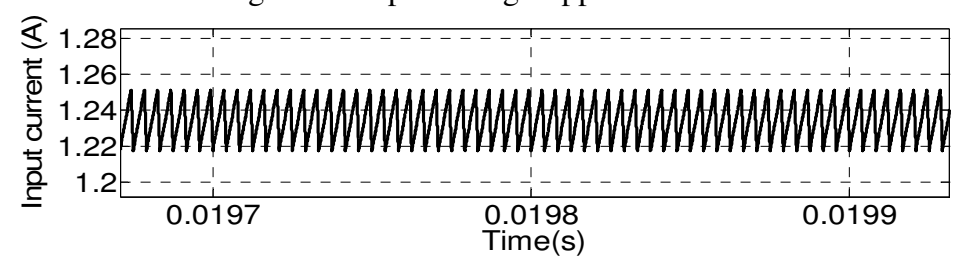

Figure 9 Input current ripple waveform

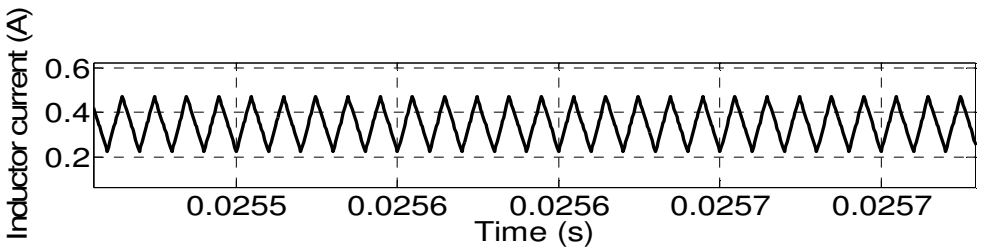

Figure 10 Inductor current ripple waveform 
International Journal of Advances in Materials Science and Engineering (IJAMSE) Vol.5, No.1, January 2016

\section{Closed loop scheme}

There are in general two modes of control-voltage mode control and current mode control. Voltage mode control is achieved by comparing the output voltage with the reference voltage and the produced error signal is then compared with a fixed frequency ramp signal to produce the PWM pulses to the converter. But such a control results in sluggish response. Also, the output filter complicates the circuit compensation, which is even more difficult due to the fact that the loop gain varies with input voltage [13]. In order to overcome such drawbacks, the current loop control scheme is used here.

\subsection{Blocked diagram of closed loop current control mode:}

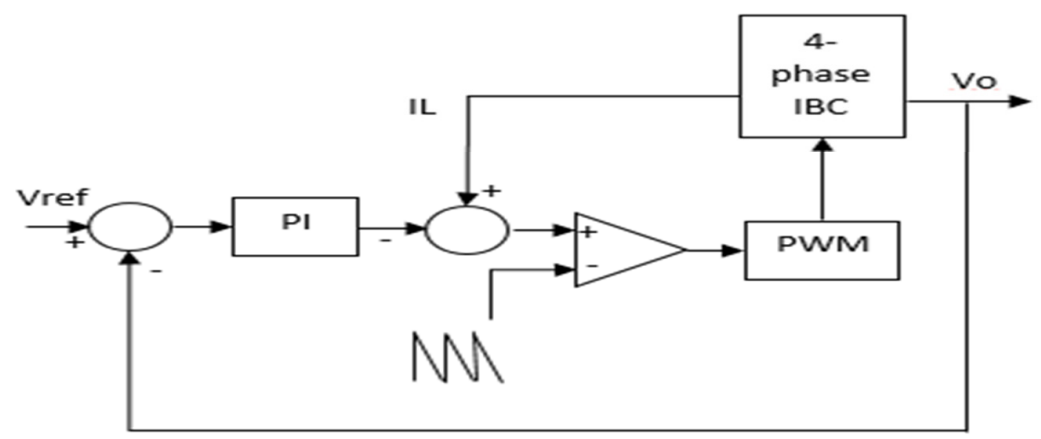

Figure 11 Closed loop mode block diagram

The block diagram for closed loop control is shown in figure 11 . Here, the output voltage, $V_{\mathrm{o}}$ is compared with the set reference voltage, $\mathrm{V}_{\text {ref }}$. The difference between the two produces an error which is then given to the PI controller block. The output of the PI controller block is then compared with the inductor current (IL) of the converter which inturn is compared with the sawtooth waveform to produce the PWM pulse. The obtained PWM pulse is then given to the gate of the switches used in the converter [14].

The current control mode addresses the slow response of the voltage mode control. Here the inductor current rises with a slope determined by the difference between the input and output voltages and so it responds immediately to the line or load changes. Another advantage is that the current mode control eliminates the loop gain variation with the input voltage which is a drawback in the voltage mode control [15].

\subsection{Closed loop simulation parameters:}

The proportional and integral gain constant for the four phase boost converter in closed loop operation are shown in table 2 [16].

\begin{tabular}{|c|c|}
\hline Parameter & Value \\
\hline kp & 0.5 \\
\hline ki & 300 \\
\hline
\end{tabular}

Table 2 Simulation parameters for closed loop operation 
International Journal of Advances in Materials Science and Engineering (IJAMSE) Vol.5, No.1, January 2016 6.3 Closed loop simulation results:

The waveforms for the closed loop current control operation of the four phase boost converter is shown in figures 12,13 and 14 .

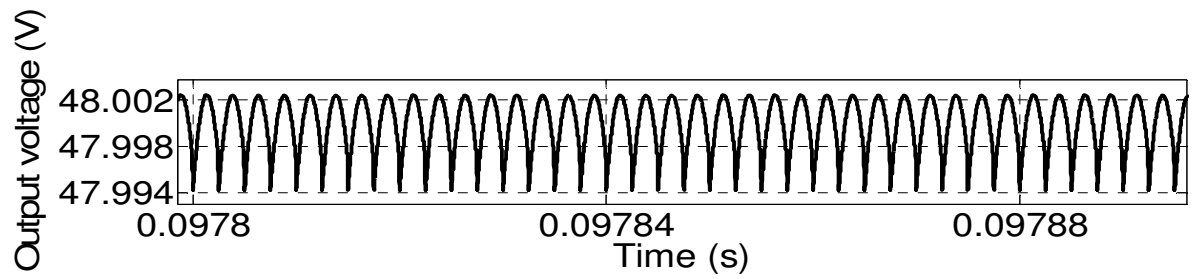

Figure 12 Output voltage ripple waveform

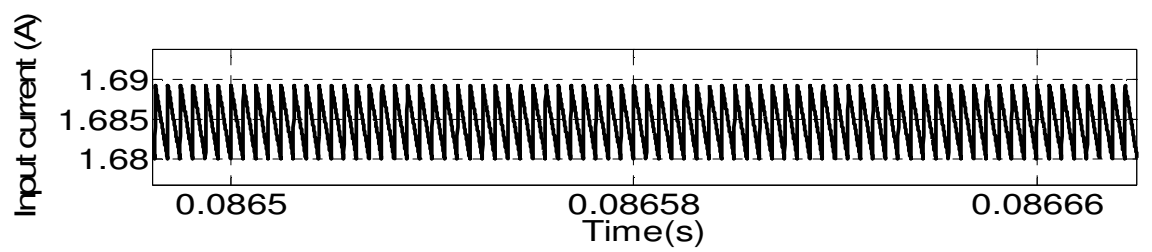

Figure 13 Input current ripple waveform

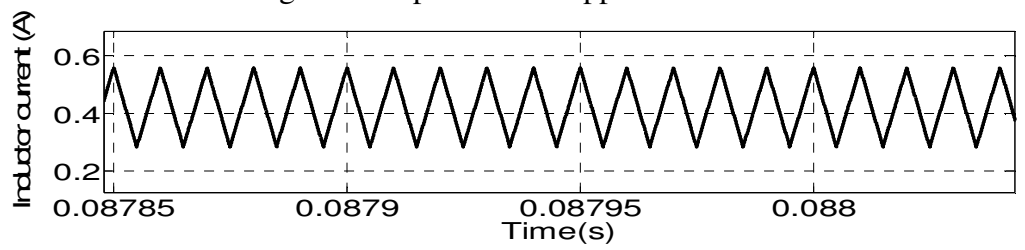

Figure 14 Inductor current ripple waveform

\section{Comparison of open loop and closed loop results:}

In simulating the open and closed loop of four phase interleaved boost converter, the output voltage ripple and input current ripple was different. It is found that the closed loop control scheme has lesser ripple compared to the open loop control scheme. From the results obtained in [17] and [18], it can be found that compared to the conventional boost converter and interleaved boost converter, the four phase closed loop interleaved boost converter drastically reduces the ripple in both the output voltage and input current.

\begin{tabular}{|c|c|c|}
\hline Parameter & Open loop & Closed loop \\
\hline $\begin{array}{c}\text { Output } \\
\text { voltage ripple } \\
(\%)\end{array}$ & 0.0608 & 0.0166 \\
\hline $\begin{array}{c}\text { Input current } \\
\text { ripple (\%) }\end{array}$ & 2.554 & 0.711 \\
\hline $\begin{array}{c}\text { Inductor } \\
\text { current ripple } \\
(\%)\end{array}$ & 71.86 & 65.55 \\
\hline
\end{tabular}

Table 3 Comparison of open and closed loop results 
International Journal of Advances in Materials Science and Engineering (IJAMSE) Vol.5, No.1, January 2016

\section{Conclusion:}

The four phase boost converter was simulated both in open and closed loop modes. It was found that the input current, output voltage ripple and capacitor RMS current was found to be lowest at duty cycles $25 \%, 50 \%$ and $75 \%$. Also, closed loop current control was applied to the four phase boost converter. As a result of closed loop operation, it was found that the ripple values for the closed loop operating scheme is less compared to the open loop operationas shown in table 3 . Therefore, in places where the ripple values should be maintained less like in battery charging applications, interleaving phenomenon is much advantageous compared to the conventional boost converter. Furthermore, the closed loop operating scheme tends to be an added advantage for the four phase interleaved boost converter to operate with less ripples.

\section{References:}

[1] S. Kamtip, K. Bhumkittipich, "Design and Analysis of Interleaved Boost Converter for Renewable Energy Applications", 9 ${ }^{\text {th }}$ Eco-Energy and Materials Science and Engineering Symposium, Chiang Rai, Thailand 25-28, May 2011.

[2] Ahmad Saudi Samosir, Taufi, Abd Jaafar Shafie, Abdl Halim Mohd Yatim, "Simulation and Implementation of Interleaved Boost DC-DC Converter for Fuel Cell Application", International Journal of Power Electronics and Drive System, Vol.1, No. 2, pp. 168-174, December 2011.

[3] M.N. Gitau, I.W. Hofsajer, "Analysis of 4-phase tapped-inductor DC-DC converter for high boost ratio wide input voltage range applications" IEEE, Industrial Electronics Society, IECON 2014, pp. 5468-5474, November 2014.

[4] Po-Wa Lee, Yim-Shu Lee, David K.W. Cheng, Xiu-Cheng Liu, "Steady-State Analysis of an Interleaved Boost Converter with Coupled Inductors", IEEE Trans. On Industrial Electronics, Vol. 47, No. 4, August 2000.

[5] Nagulapati Kiran, V. Rangavalli, B. Vanajakshi, "Modelling, Analysis and Simulation of 4phase Boost Converter", International Journal of Electrical, Computer, Energetic, ellectronic and Communication Engineering, Vol.8, No.9, 2014.

[6] M. Omamageswari, Y. Thiyagarajan, C.T.S. Sivakumaran, "Interleaving Technique in Multiphase Buck \& Boost Converter", ACEEE International Journal on Control System and Instrumentation, Vol. 3, No. 2, March 2012.

[7] Saching K. Kupati, Mukul chavan, Sunil Bhattad and N. Arun, "Average Current Mode Controlled Power Factor Correction Converter", Indian Journal of Science and Technology, Vol 8(S2), pp. 53-57, January 2015.

[8] G. Seshagiri Rao, S. Raghu, N. Rajasekaran, "Design of Feedback Controller for Boost Converter Using Optimization Tecchnique", International Journal of Power Elecctronics and Drive System, Vol.3, No.1, pp.117-128, March 2013.

[9] Shih-jen Cheng, Shu-Wei Kuo, Yu-Kang Lo, Huang-Jen Chiu, "Study and implementation of four-phase interleaved 1-kW boost DC-to-DC converter for fuel cell applications", IET, Power

Electronics, Machines and Drives, pp. 1-6, March 2012.

[10] V.B. Nancy, V. Karthikeyan, "Solar Based Stand Alone High Performance Interleaved Boost Converter with ZVS and ZCS", IOSR Journal of Electrical and Electronics Engineering, Vol. 5, Issue 4, pp. 22-28, May 2013. 
International Journal of Advances in Materials Science and Engineering (IJAMSE) Vol.5, No.1, January 2016

[11] Saubhik Maulik, Pradip Kumar Saha, Goutham Kumar Panda, "Power Factor Correction By Interleaved Boost Converter Using PI Controller", International Journal of Engieering Research and Applications, Vol. 3. Issue 5, pp. 918-922, October 2013.

[12] P. Li and B Lehman, "A design method for paralleling current mode controlled DC-DC converters”, IEEE Trans. On Power Electronics., Vol.19, No.3, May 2004.

[13] S. Chattopadhyay and S. Das, "A Digital Current Mode Control technique for DC-D Converters" in Proc. Vol.2, pp. 885-891, APEC 2005.

[14] U.R. Prasanna, A.K. Rathore, "Two loop average current control implementation using cypress PSoC with closed loop experimental results”, IEEE, Energy Conversion Congress and Exposition, pp. 4199-4206, September 2013.

[15] Turki Kahawish Hassan, “A Repetitive-PI Current Controller for Boost Single Phase PFC Converters”, pp. 69-78, Energy and Power Engineering, 2011.

[16] Mitulkumar R. dave, K.C. Dave, "Analysis of Boost Coverter using PI control algorithms", International Journal of Engineering Trends and Technology, Vol.3, Issue 2, 2012.

[17] R. Seyezhai, "Analysis and Implementation of Interleaved Boost Converter for Fuel Cell System”, Vol. 2, Issue 3, pp. 30-34, Journal of electrical and Control Engineering, 2012.

[18] R. Seyezhai, "Design, Simulation and Hardware Implementation of a Multi Device Interleaved Boost Converter for Fuel Cell Applications”, Vol. 4, No. 3, pp. 314-320, International Journal of Power Electronics and Drive System, September 2014. 